\title{
第59回 日本視能矯正学会
}

\section{一般講演}

\section{視能障害による自覚的歩行困難の評価方法についての検討}

\author{
正条 智広 ${ }^{12}{ }^{2)}$ ・岡 真由美 ${ }^{1)}$ ・野口 菜摘 ${ }^{2)} \cdot$ 岸 大介 ${ }^{2)} \cdot$ 田淵 仁志 $^{2)}$ \\ 1) 川崎医療福祉大学大学院感覚矯正学専攻 \\ 2) ツカザキ病院 眼科
}

\section{An Integrated Evaluation Method for Subjective Mobility Difficulties}

\section{Originating from Visual Impairment}

\author{
Tomohiro Shoujou ${ }^{1),}{ }^{2)}$, Mayumi Oka ${ }^{1)}$, Natsumi Noguchi ${ }^{2)}$, \\ Daisuke Kishi ${ }^{2}$, Hitoshi Tabuchi ${ }^{2)}$ \\ 1) Department of Sensory Science, Graduate School, Kawasaki University of Medical Welfare \\ 2) Department of Ophthalmology, Tsukazaki Hospital
}

要 約

【目的】視能障害による自覚的歩行困難への影響を評価するため質問票を作成し、統計解析により 構造を明らかにした。また質問票の得点とFunctional Vision Score（FVS）との関連を検討した。

【対象および方法】対象は周辺視野の障害を有する患者 82 例で、平均年齢は $62.6 \pm 11.7$ 歳であった。 疾患の内訳は、網膜色素変性 53 例、緑内障 29 例であった。視能評価は視力および視野検查により、 Functional Acuity Score (FAS)、Functional Field Score（FFS）、FVSを算出した。歩行困難の 自覚的評価は、「歩行に関する質問票（質問票）」を使用した。統計解析は主成分分析を行い、主成 分得点を求めた。質問票に対する視能の影響度を求めるため、目的変数を主成分得点、説明变数を FAS、FFS、FVSとして重回帰分析を行った。

【結果】質問票の主成分分析により、第 1 主成分は「段差の把握」と決定した。重回帰分析により

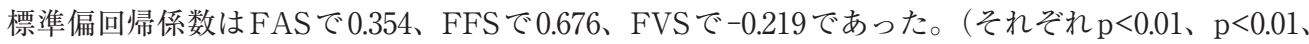

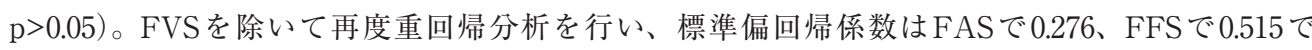
あった（それぞれ $\mathrm{p}<0.01 ） 。$

【結論】質問票は段差の把握の項目により自覚的歩行困難の特性を評価することが可能であった。 質問票はFFS、FASの順に影響度が高かった。

別冊請求先（广 671-1227）兵庫県姫路市網干区和久 68-1

Tel. 079 (272) 8555 Fax. 079 (272) 8550

E-mail : t.shojo@tsukazaki-eye.net

Key words : 視能障害、歩行、質問票、Functional vision score、視野 visual impairment, mobility, questionnaire, functional vision score, visual field 


\section{Abstract}

【Purpose】 To assess the effects of visual impairments on subjective mobility difficulties, we developed a questionnaire and its structure was analyzed statistically. The association between the questionnaire score and functional vision score (FVS) was also investigated.

【Subjects and Methods】 Subjects were 82 adults (mean age, $62 \pm 11.7$ years) with impaired peripheral vision including retinitis pigmentosa (53 patients) and glaucoma (29 patients). Subjects were given visual acuity and visual field tests and the results were used to calculate functional acuity score (FAS), functional field score (FFS), and FVS. Outdoor mobility difficulties were subjectively assessed using the Outdoor Mobility Questionnaire (OMQ)(developed in this study). For statistical analysis, principal component analysis (PCA) was performed and principal component scores (PCSs) were calculated. To determine if the questionnaire outcome (the PCSs) was influenced by vision-related scores (the FAS, FFS, and FVS), multiple regression analysis was conducted using the PCSs as the objective variable and the FAS, FFS, and FVS as the explanatory variables.

【Results】 By PCA, the questionnaire items related to " perceiving an unleveled surface" were found to be the first principal component (PC1). By multiple regression analysis, the standard partial regression coefficients for FAS, FFS, and FVS were $0.354(P<0.01), 0.676(P<0.01)$, and $-0.219(P>0.05)$, respectively. Multiple regression analysis was performed again without FVS and different coefficients of 0.276 and 0.515 were respectively yielded for FAS and FFS (both $P<$ $0.01)$.

【Conclusion】 The OMQ items related to "perceiving an unleveled surface" could evaluate the characteristic of subjective mobility difficulties. FFS followed by FAS appeared to have a strong influence on the questionnaire score.

\section{I 緒言}

視能とは「視る能力」をいい、日常生活行 動、動作の基盤となる ${ }^{1)}$ 。したがって視能障害 ${ }^{2)}$ は視機能の障害がQuality of life（以下、QOL) の低下をきたしている状態を表す。視能障害に よる歩行困難は、世界保健機関が採択した国際 生活機能分類 ${ }^{3)}$ において活動制限や参加制限の 要因となる重要な問題である。

視能障害と歩行の関係についての過去の研究 では、アンケート形式の調査や、実際に実験 コースを作成して歩行速度や障害物への接触の 回数などの歩行パフォーマンスを調查したもの

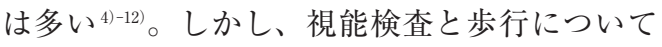
の詳細な聞き取り調査結果との総合評価を歩行 訓練へと繋げる報告はない。

今回、視能障害による自覚的歩行困難を評価 する質問票を作成し、その構造を明らかにする ため各項目の視能の影響度を検討した。

\section{III対象および方法}

\section{1. 対象}

対象は、ツカザキ病院眼科に通院している周 辺視野障害を有する患者 82 例で、男性46例、 女性 36 例であった。年齢は平均 $62.6 \pm 11.7$ 歳で あった。疾患の内訳は網膜色素変性が 53 例、緑 内障が29例であった。

対象者の除外条件は、視能障害以外に歩行困 難の原因となる下肢麻疩、内部障害、脳外科疾 患などの身体的問題を有するもの、認知の問題 が疑われるものとした。

対象者の良好眼の遠見視力は小数視力 $0.01 〜$ 1.5 であった。また、視野障害の主なタイプは、 求心性視野狭窄、輪状暗点、周辺視野欠損、中 心および周辺視野欠損の複合などであった。

\section{2. 視能検査}

視能検査は、視力および動的視野検査を行っ た。視力検查は $5 \mathrm{~m}$ の遠見視力とし、片眼ず つと両眼開放下で裸眼視力と矯正視力を測定 
した。視野検査はProjection Perimeter MT325UD（TAKAGI社）を使用し片眼ずつ測定 した。

\section{3. 視能解析}

視能解析のため、視能検査の結果をスコア 化（以下、視能スコア）した。視能スコアは Functional Vision Score (以下、FVS) ${ }^{13)}{ }^{14)}$ を 用いた。FVSは視力を評価するFunctional Acuity Score（以下、FAS）と視野を評価す るFunctional Field Score（以下、FFS）を 統合的に評価する方法で、計算式 $[F V S=F A S$ $\times F F S / 100]$ で求める。FVSを求めるために、 FASとFFSを算出した。また、FVSの結果を もとに対象者を American Medical Association （以下 AMA） class $^{15)}$ の基準で分類した。

FASは第一に片眼ずつと両眼開放での Visual Acuity Score（以下、VAS）を計算式 $\left[V A S=100+50 \times \log _{10}\right.$ (小数視力) $]$ で求めた。第二 に片眼と両眼開放の加重平均を求めるため計算 式 $[F A S=($ 右 VAS+左 VAS $+3 \times$ 両VAS $) / 5]$ で FASを算出した。
FFSは第一に片眼ずっと両眼でのVisual Field Score（以下、VFS）を求めた。VFSは動 的視野検查の III $/ 4$ 視標のイソプター内にあるス コアポイントの合計数で算出した。FFSの配点 を図 1 に示す。第二に片眼ずつのVFS と両眼で 重ね合わせたVFSを加重平均するよう、計算式 $[F F S=($ 右 VFS+左 VFS $+3 \times$ 両VFS $) / 5]$ でFFS を算出した。

\section{4. 自覚的歩行困難の評価}

自覚的歩行困難の評価を行うため、菊入 ${ }^{16)} の$ 歩行・行動評価票を参考にして新たに歩行に 関する質問票（以下、質問票）を作成した（図 $2 \mathrm{a} 、 \mathrm{~b})$ 。本研究では、歩行・行動評価票に視力 や視野以外の視能を評価する項目などを追加し た34項目を「自覚的歩行困難について」のカテ ゴリーとし、その中から視能に関連する 31 項目 を分析に使用した。

各質問項目の回答スケールは、困難の頻度を 示す「ない（3点）、ほとんどない（2点）、とき どきある (1点)、ある (0点)」と可不可を回答 する「可能 (3点)、難しいこともある (2 点)、

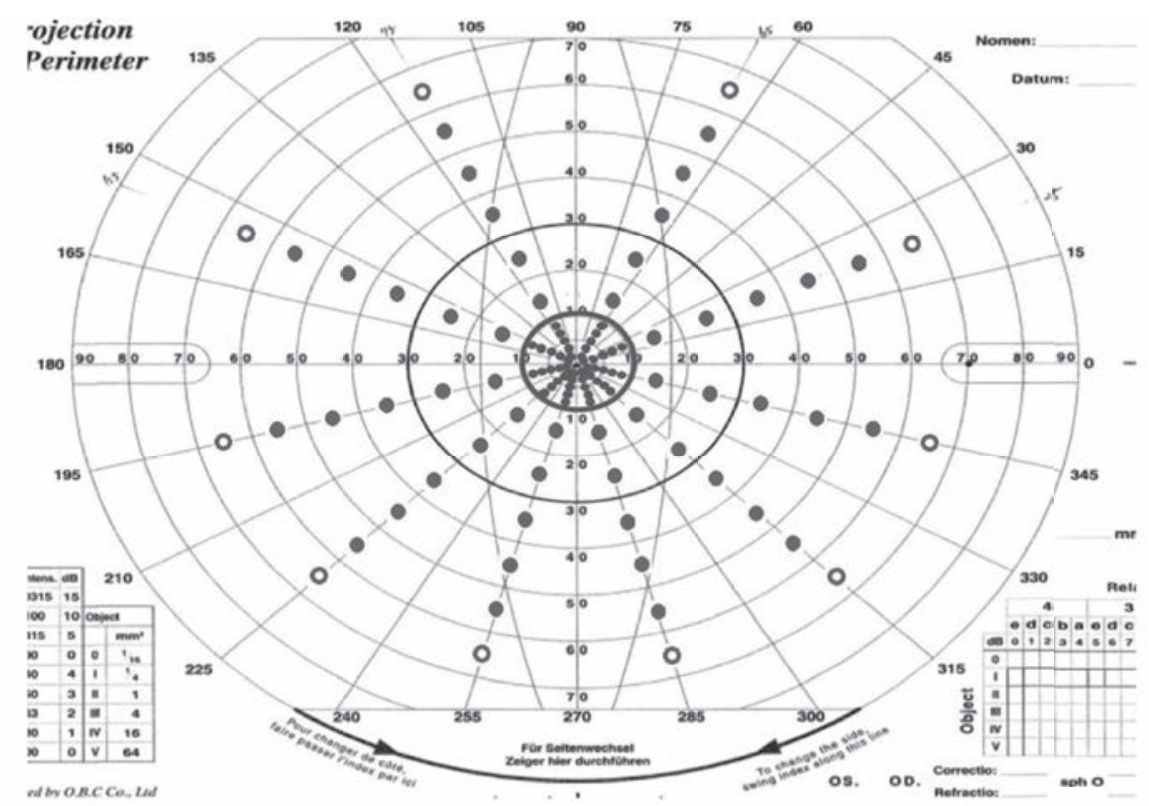

図 1 動的視野内に扔ける Functional Field Scoreの配点例 配点は視野の中心 10 度以内が 50 点、 10 度から 55 度までが 50 点となっている。また下方 視野は重みがつけられ 60 点、上方視野は 40 点である (図中のの)。今回は、オプションで ある周辺視野 65 度の 10 点（図中の○）を含めて検討した。 
取得日：

取得者:

同意いただける方は右のチェックボックスにチェックを入れてください ロ

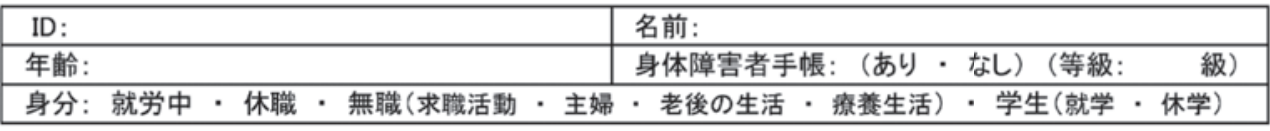

1)全身の状態について

下肢の問题を医師から指摘されたことがありますか 聴賞の問題を医師から指摘されたことがありますか 脳の問题を医師から指摘されたことがありますか その他、医師から指摘された病気はありますか

\begin{tabular}{|c|ccc|}
\hline & ある・ない & 具体的な疾患名など( & ・ \\
\hline & ある・ない & 具体的な疾患名など( & ) \\
\hline & ある・ない & 具体的な疾患名など( & ) \\
\hline & ある・ない & 具体的な疾患名など( & ・
\end{tabular}

2)現在の歩行状況と外出状況について ※当てはまるものすべてに○をつけてください

\begin{tabular}{|c|c|}
\hline 主な外出目的は何がありますか & 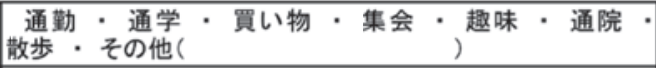 \\
\hline 外出の頻度はどの程度ですか (1週間に) & 外出しない $\cdot$ 1日～3日 $\cdot$ 4日 6日 $\cdot$ 毎日 \\
\hline 外出の時間带はいつですか & 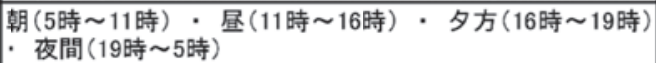 \\
\hline その他、利用している歩行の方法は何ですか & 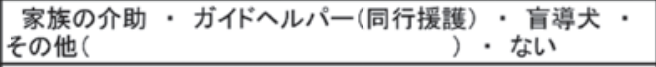 \\
\hline 歩行補助具の利用はありますか & 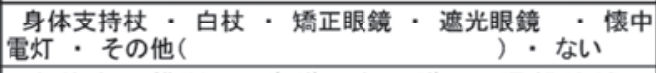 \\
\hline 難易度の高い歩行環境はありますか & $\begin{array}{c}\text { そ交差点の横断 ·歩道の無い道・混雑地域・ } \\
\text { その他（ }\end{array}$ \\
\hline 普段利用している公共交通機関は何ですか & $\begin{array}{r}\text { 電車 } ・ \text { バス・ない } \\
\end{array}$ \\
\hline どんな天候の時が歩きやすいですか & 晴 $\cdot$ 車・雨・ない \\
\hline
\end{tabular}

\section{3）自賞的歩行困難について} 〈一般事項〉

\begin{tabular}{|c|c|c|c|c|}
\hline 評価項目 & \multicolumn{4}{|c|}{ 該 当 } \\
\hline 単独歩行について困難や不安を感じていますか & \multicolumn{4}{|c|}{ 感じていない・感じている } \\
\hline 車道などの白線を視賞で把握することができますか & 可能 & ・難しいこともある & · ほとんど不可能 & ・不可能 \\
\hline 歩道上の縁石を視覚で把握することができますか & 可能 & ·難しいこともある & •ほほとんど不可能 & - 不可能 \\
\hline 歩道上の障害物にぶつかることがありますか & ない & • ほほとんどない & ・ときどきある & ・ ある \\
\hline 路面の凹でヒヤリとすることがありますか & ない & ほとんどない & ときどきある & ある \\
\hline 人とのすれ違いで触れることがありますか & ない & ほとんどない & ときどきある & ある \\
\hline 歩車道の段差(高さ)を視覚で把握することができますか & 可能。 & ・難しいこともある & - ほとんど不可能 & - 不可能 \\
\hline 歩車道の段差(落差)を視覚で把握することができますか & 可能 & ·難しいこともある & · ほとんど不可能 & - 不可能 \\
\hline \multirow{5}{*}{ 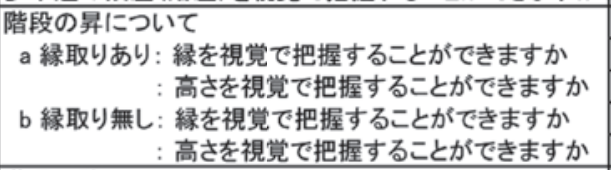 } & & & & \\
\hline & 可能 & ・ 難しいこともある & • ほとんど不可能 & - 不可能 \\
\hline & 可能 & ・難しいこともある & ・ ほとんど不可能 & ・不可能 \\
\hline & 可能 & ・難しいこともある & ••ほとんど不可能 & - 不可能 \\
\hline & 可能 & · 難しいこともある & - ほとんど不可能 & - 不可能 \\
\hline \multirow{5}{*}{ 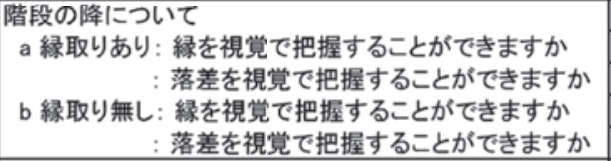 } & & & & \\
\hline & 可能 & ・難しいこともある & • ほとんど不可能 & - 不可能 \\
\hline & 可能 & ・ 難しいこともある & ••ほとんど不可能 & ・不可能 \\
\hline & 可能 & ・ 難しいこともある & • ほとんど不可能 & - 不可能 \\
\hline & 可能 & ・難しいこともある & ・ ほとんど不可能 & ・ 不可能 \\
\hline 踊り場、最上·下階で二度踏みすることがありますか & ない & ·・ ほとんどない & ·ときどきある & ・ ある \\
\hline \multicolumn{5}{|l|}{ 信号機の色の把握はできますか } \\
\hline & 可能 & ・ 難しいこともある & • ほとんど不可能 & • 不可能 \\
\hline b 逆行では & 可能 & ・ 難しいこともある & •・ほとんど不可能 & · 不可能 \\
\hline c 夜間は & 可能 & ・ 難しいこともある & · ほとんど不可能 & - 不可能 \\
\hline 色の把握はできますか & 可能。 & ・難しいこともある & • ほとんど不可能 & - 不可能 \\
\hline 目印や目標物を探し出すことができますか & 可能 & ・難しいこともある & ・ ほとんど不可能 & ・不可能 \\
\hline 夜間の歩行は可能ですか & 可能 & · 難しいこともある & • ほとんど不可能 & - 不可能 \\
\hline
\end{tabular}


その他歩行で不安·困難なことはありますか(自由回答)

\begin{tabular}{|c|c|}
\hline 評価項目(パス) & 当 \\
\hline バス停を視覚で発㒻することができますか & 可能 ・ 難しいこともある ・ ほとんど不可能 ・ 不可能 \\
\hline 接近するバスを視覚で発見することができますか & 可能 ・ 難しいこともある ・ ほとんど不可能 ・ 不可能 \\
\hline 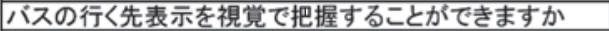 & 可能 ・ 難しいこともある ・ ほとんど不可能 ・ 不可能 \\
\hline 整理券発行·料金の支払の動作はできますか & 可能 ・ 難しいこともある ・ ほとんど不可能 \\
\hline \multicolumn{2}{|l|}{ その他、不安·困難なことにこいて(自由回答) } \\
\hline 評価項目(電車) & 該 当 \\
\hline 駅構内に入った時の暗順応の遲延 & ない ・ ほとんどない $\quad$ ほ $\quad$ ときどきある \\
\hline $\begin{array}{l}\text { 利用している駅の料金表を視覚で把握することができま } \\
\text { すか }\end{array}$ & 可能 · 難しいこともある - ほとんど不可能 · 不可能 \\
\hline 切符の自動販売機を視覚で利用することができますか & 可能 ・ 難しいこともある ・ ほとんど不可能 ・ 不可能 \\
\hline プラットホーム上の歩行の不安はありますか & ない $\cdot$ なとんんどない $\quad$ ほ \\
\hline $\begin{array}{l}\text { プラツトホームの表示(ナンバー)を視賞で把握することが } \\
\text { できますか }\end{array}$ & 可能 · 難しいこともある - ほとんど不可能 · 不可能 \\
\hline $\begin{array}{l}\text { プラットホームの白線、点字ブロックを視覚で把握すること } \\
\text { ができますか }\end{array}$ & 可能 · 難しいこともある - ほとんど不可能 · 不可能 \\
\hline 電車の乗降に不安を持つ事項について(自由回答) & \\
\hline 不安·困難なこと(自由回答) & \\
\hline
\end{tabular}

\section{<追加事項〉}

\begin{tabular}{|c|c|c|c|c|}
\hline 物が2重に見えることがありますか & ない & ほとんどない & ·～ときどきある & • ある \\
\hline まぶしさで見えづらいことがありますか & ない & ほとんどない & ときどきある & ・ ある \\
\hline $\begin{array}{l}\text { 屋内から屋外へ出たときに見え方が慣れるまで時間がか } \\
\text { かることがありますか }\end{array}$ & ない & · ほとんどない & ・ ときどきある & ・ ある \\
\hline $\begin{array}{l}\text { 屋外から屋内へ入ったときに見え方が慣れるまで時間が } \\
\text { かることがあります }\end{array}$ & ない & · ほとんどない & · ときどきある & ・ ある \\
\hline $\begin{array}{l}\text { 上部にある商店の看板や公共施設などの案内表示を視 } \\
\text { 覚で握することができますか }\end{array}$ & 可能 & ・ 難しいこともある & • ほとんど不可能 & · 不可能 \\
\hline (目の高さより上の)障害物にぶつかることがありますか & ない & ほとんどない & ときどきある & ・ ある \\
\hline (左右にある)障害物にぶつかることがありますか & ない & ほとんどない & ときどきある & ・ ある \\
\hline $\begin{array}{l}\text { 車や人が横切るのに直前まで気が付かないことがありま } \\
\text { すか }\end{array}$ & ない & ほとんどない & · ときどきある & • ある \\
\hline 正面から歩いてくる人の顔が視覚で把握できますか & 可能 & ・難しいこともある & • ほとんど不可能 & · 不可能 \\
\hline $\begin{array}{l}\text { 歩行する際に、自分がいる場所と、目的地との位置関係 } \\
\text { がわかりますか }\end{array}$ & 可能 & · 難しいこともある & · ほとんど不可能 & · 不可能 \\
\hline $\begin{array}{l}\text { 音を聞いて、その音がどの方向から鳴っているかがわか } \\
\text { りますか }\end{array}$ & 可能 & · 難しいこともある & - ほとんど不可能 & · 不可能 \\
\hline 足で路面の変化を感じ取ることができますか & 可能 & ・難しいこともある & • ほとんど不可能 & • 不可能 \\
\hline
\end{tabular}

4) 視賞障害者の歩行技術や歩行判練について

\begin{tabular}{|c|c|}
\hline $\begin{array}{l}\text { 視覚障害者に対する歩䘕訓練について知っていますか } \\
\text { (白杖、白杖操作、屋内移動技術 など) }\end{array}$ & 知っている - 知らない \\
\hline $\begin{array}{l}\text { ヒューマンガイドテクニック(ガイドヘルプ)と同行援護につ } \\
\text { いて知っていますか }\end{array}$ & 知っている · 知らない \\
\hline $\begin{array}{l}\text { 眼科医療機関で歩行技術や歩行訓練についていままで } \\
\text { に情報提供があまました } \\
\end{array}$ & あった · なかった \\
\hline $\begin{array}{l}\text { 視賞障害者自立訓練施設などで歩行訓練や生活訓練を } \\
\text { 受けたこがりますか }\end{array}$ & ある ・ ない \\
\hline
\end{tabular}

ご協カありがとうございました。

図 $2 \mathrm{~b}$ 歩行に関する質問票（2ページ目） 
ほとんど不可能 (1 点)、不可能 (0 点)」の 4 段 階を設定した。質問票の調査は対面式で対象者 本人に調查者が口頭で質問項目と回答項目を読 み上げて実施した。

\section{5. 統計解析}

視能障害者の歩行について影響が強い項目を 抽出するために主成分分析を行った。主成分分 析では質問票の各項目の主成分への関係の強さ を表す因子負荷量を求めた。主成分に含まれる 項目は、因子負荷量が高い順に並び変え、特に 重要な項目を集約して歩行行動の総合能力を説 明づけた。また、項目ごとの固有值に対応する 固有ベクトルから計算式を導き出し、観測值を 主成分に代入して得られる主成分得点を求め た。統計処理は多変量解析ソフト Mulcelを使用

し、有意水準を $5 \%$ 未満とした。

質問票の得点に対する視能の影響度を求める ために、目的変数を主成分得点、説明変数を視 能スコアとして算出したFAS、FFS、FVSとし て重回帰分析を行った。また、目的変数と説明 変数の関係を表す重回帰モデルを作成した。統 計処理は統計解析ソフト Statcel ver.4を使用し、 有意水準を $5 \%$ 未満とした。

\section{6. 倫理的配慮}

本研究は、川崎医療福祉大学の倫理審査（承 認番号 17-066）およびッカザキ病院での倫理 審査（承認番号 171023）での承認を得た。

\section{III 結果}

\section{1. 対象者の視能スコアと国際分類}

対象者の各視能スコアの平均值 \pm 標準偏差 を示す。FVSは $45.8 \pm 27.4 、 F A S は 82.5 \pm 27.3 、$ FFSは $51.2 \pm 24.3$ であった。
FVSを基準としたAMA class と視覚喪失の国 際分類を示す（表1）。「正常視覚」が4例、「軽

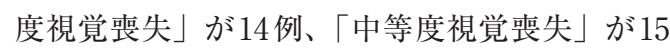
例、「重度視覚喪失」が 20 例、「極度視覚喪失」 が17例、「(ほとんど）全視覚喪失」が 12 例で あった。

\section{2. 質問票の構造}

質問票の項目に対する主成分分析の結果を示 す（表 2$)$ 。固有值が 1 以上となる主成分は第 6 主成分まで抽出された。第 1 主成分に含まれる 項目は「階段の降り・縁取り無し：縁を視覚で 把握する」、階段の降り・縁取り無し：落差を 視覚で把握する」、「歩車道の段差（落差）を視 覚で把握する」などで、階段昇降や歩車道の段 差の把握に関する成分（以下、段差の把握成 分）と決定した。第 1 主成分の寄与率は $44.3 \%$ であった。第2主成分に含まれる項目は、「(左 右にある）障害物にぶつかる」、「屋外から屋内 へ入ったときに見え方が慣れるまで時間がか る」「屋内から屋外へ出たときに見え方が慣れ るまで時間がかかる」であり外側の障害物回避 と明暗順応（以下、外側・順応成分）と決定し た。第 2 主成分の寄与率は $11.5 \%$ であった。第 3 主成分に含まれる項目は、「まぶしさで見えづ らい」であり、羞明成分と決定した。第 3 主成 分の寄与率は $5.8 \%$ であった。第 4 主成分以降は 寄与率が $5 \%$ 未満で低いため、検討から除外し た。

\section{3. 視能スコアと自覚的歩行困難との関係}

第 1 から第 3 主成分の主成分得点を目的変数 とし、説明変数をFAS、FFS、FVSとして重 回帰分析を行った（表3a）。各主成分において、 説明変数の相対的な目的変数への影響力を示す 標準回帰係数を求めた。

表1 AMA ClassにおけるFVSを基準にした症例の分類

\begin{tabular}{|c|c|c|c|}
\hline FVS & AMA class & 分類 & $\mathrm{n}$ \\
\hline $100-93$ & Class 0 & 正常視覚 & 4 \\
\hline $92-73$ & Class 1 & 軽度視覚喪失 & 14 \\
\hline $72-53$ & Class 2 & 中等度視覚喪失 & 15 \\
\hline $52-33$ & Class $3 a$ & 重度視覚表失 & 20 \\
\hline $32-13$ & Class $3 b$ & 極度視覚表失 & 17 \\
\hline $12-0$ & Class 4 & (ほとんど) 全視覚喪失 & 12 \\
\hline
\end{tabular}


表2＼cjkstart質問票の各主成分における因子負荷量

\begin{tabular}{|c|c|c|c|}
\hline \multirow{3}{*}{ 筫問項目 } & \multicolumn{3}{|c|}{ 因子負荷量 } \\
\hline & 第1主成分 & 第2主成分 & 第3主成分 \\
\hline & 段差の把握成分 & 外側·順応成分 & 䖯明成分 \\
\hline 鄀段の降り·緣取り無し:緣を視覚で把握する & 0.877 & -0.191 & -0.074 \\
\hline 鄢段の降り·緣取り無し:落差を視賞で把握する & 0.868 & -0.176 & -0.051 \\
\hline 歩車道の段差(落差)を視賞で把握する & 0.836 & -0.173 & -0.034 \\
\hline 歩車道の段差(高さ)を視覚で把握する & 0.800 & -0.257 & -0.052 \\
\hline 階段の昇り·縁取り無し:縁を視覚で把握する & 0.793 & -0.273 & -0.062 \\
\hline 晆段の昇り·緣取り無し:高さを視賞で把握する & 0.772 & -0.214 & -0.087 \\
\hline 歩道上の緣石を視覚で把握する & 0.764 & -0.182 & -0.004 \\
\hline 踊り場、最上·下階でニ度踏みする & 0.741 & 0.258 & -0.286 \\
\hline 階段の降り·縁取りあり:落差を視覚で把握する & 0.716 & -0.362 & 0.121 \\
\hline 频段の昇り·縁取りあり:高さを視覚で把暒する & 0.695 & -0.447 & 0.000 \\
\hline 車や人が橫切るのに直前まで気が付かない & 0.695 & 0.148 & -0.435 \\
\hline 上部にある商店の看板や公共施設などの案内表示を視賞で把握する & 0.689 & -0.422 & -0.024 \\
\hline 路面の凹でヒヤリとする & 0.678 & 0.210 & -0.087 \\
\hline 色の把握 & 0.677 & -0.401 & 0.065 \\
\hline 歩道上の障害物にぶつかる & 0.676 & 0.316 & 0.055 \\
\hline 夜間の歩行 & 0.671 & 0.018 & 0.035 \\
\hline 正面から歩いてくる人の顔が視覚で把握する & 0.660 & -0.457 & 0.113 \\
\hline 信号機の色の把握: 逆行 & 0.637 & -0.250 & 0.267 \\
\hline (左右にある) 障害物にぶつかる & 0.613 & 0.551 & -0.181 \\
\hline 目印や目橾物を探し出す & 0.609 & -0.364 & -0.030 \\
\hline 屋内から屋外へ出たときに見え方が慣れるまで時間がかかる & 0.604 & 0.534 & 0.396 \\
\hline 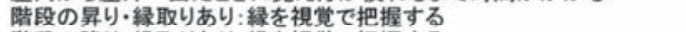 & 0.588 & -0.327 & 0.181 \\
\hline 階段の降り·縁取りあり:縁を視賞で把握する & 0.585 & -0.310 & 0.218 \\
\hline (目の高さより上の)障害物にふらうかる & 0.580 & 0.305 & -0.342 \\
\hline 人とのすれ遗いで触れる & 0.576 & 0.440 & -0.055 \\
\hline 信号機の色の把握: 順光 & 0.552 & -0.350 & 0.133 \\
\hline 車道などの白線を視覚で把握する & 0.549 & -0.163 & 0.109 \\
\hline まぶしさで見えつらい & 0.540 & 0.029 & 0.483 \\
\hline 信号機の色の把握: 夜間 & 0.485 & -0.383 & 0.150 \\
\hline 屋外から屋内へ入ったときに見え方が慣れるまで時間がかる & 0.462 & 0.541 & 0.518 \\
\hline 物が2重に見える & 0.328 & -0.022 & 0.010 \\
\hline 固有値 & 13.557 & 3.526 & 1.783 \\
\hline 寄与率(\%) & 44.3 & 11.5 & 5.8 \\
\hline 累皘寄与率 (\%) & & 55.8 & 61.6 \\
\hline
\end{tabular}

主成分は固有值が 1 以上となる主成分は第 6 主成分まで抽出した。因子負荷量の絶対值が大きい 質問項目ほど主成分への影響度が強いことを表す。

表3 主成分得点と視能スコアとの重回帰分析

a: 説明変数 (FVS、FAS、FFS)

\begin{tabular}{|c|c|c|c|}
\hline \multirow{3}{*}{ 説明変数 } & \multicolumn{3}{|c|}{ 標準回帰係数 } \\
\hline & 第1主成分 & 第2主成分 & 第3主成分 \\
\hline & 段差の把握成分 & 外側·順応成分 & 盖明成分 \\
\hline FVS & -0.219 & 0.297 & 0.007 \\
\hline FAS & $0.354^{*}$ & $-0.765^{* *}$ & 0.103 \\
\hline FFS & $0.676^{*}$ & 0.199 & -0.005 \\
\hline 重相関係数 & 0.700 & 0.571 & 0.106 \\
\hline 決定係数 & 0.474 & 0.300 & -0.027 \\
\hline \multicolumn{4}{|c|}{ b: 説明変数 (FAS、FFS) } \\
\hline \multirow{3}{*}{ 説明変数 } & \multicolumn{3}{|c|}{ 標準回帰係数 } \\
\hline & 第1主成分 & 第2主成分 & 第3主成分 \\
\hline & 段差の把握成分 & 外側·順応成分 & 盖明成分 \\
\hline FAS & $0.276^{* *}$ & $-0.658^{* *}$ & 0.105 \\
\hline FFS & $0.515^{* *}$ & $0.417^{* *}$ & 0.001 \\
\hline 重相関係数 & 0.700 & 0.566 & 0.106 \\
\hline 決定係数 & 0.477 & 0.304 & -0.014 \\
\hline
\end{tabular}


第 1 主成分の標準回帰係数はFFSが最も高 く、次にFASであった（いずれも $\mathrm{p}<0.05 ） 。 し$ かし、FVSは標準回帰係数が負の值となり、係 数矛盾現象が起こっていた。また、FVSに対 して多重共線性があったため、説明変数を減ら し、FVSを除いたFAS とFFSで再度重回帰分 析を行った（表 $3 \mathrm{~b} ）$ 。その結果、第 1 主成分に おける標準回帰係数はFFSについでFASが高

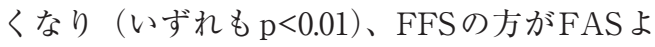
り質問票の第 1 主成分に対する影響度が有意 に強かった。重回帰式への当てはまりの良さを 示す重相関係数は 0.700 であり、残差は正規分 布に従っていた。第1主成分得点の重回帰式は 以下となった。

第 1 主成分得点 $=0.036 \times F A S+0.077 \times F F S-7.019$ 第2主成分の主成分得点とFAS、FFSとの重 回帚分析における標準回帰係数は、FASで

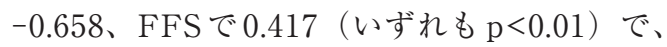
FASは係数矛盾現象をみとめた。

第 3 主成分については、視能スコアとの有意 な結果は得られなかった。

\section{IV 考按}

本研究では、周辺視野障害を有する患者を対 象に、視能障害による自覚的歩行困難を総合的 に評価するための「歩行に関する質問票」を作 成した。

\section{1. 対象疾患と視能解析の方法について}

本研究の対象疾患は網膜色素変性と緑内障で あり、周辺視野の障害から視野狭窄まで様々 な視野障害の状態があることから、視野の自覚 的歩行困難への影響度の検討に用いた。また 対象者を国際基準として採択されている $\mathrm{AMA}$ class $^{15)}$ により分類した結果、軽度視覚喪失か ら（ほとんど）全視覚喪失まで幅広く分布して おり、本研究における視能の分布として適切で あったと考えられた。

視能スコアとして用いたFVSは Colenbrander により考案され ${ }^{13)}$ 14)、AMA classに利用されて

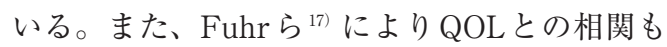
報告されている。FVSは両眼機能を重視する一 方で、片眼の障害を無視することのないよう配
慮されている特徵がある。FFSは動的視野を中 心視野から周辺視野までスコア化し、片眼ずつ と两眼の視野として加重平均して算出する方法 であり、下方視野に $60 \%$ の重み付けをして評価 できる。歩行や移動における下方視野の重要性 は過去のLovie-Kitchin ら ${ }^{11)}$ や Black ら ${ }^{12)}$ の調 査からも報告されおり、FFSは自覚的歩行困難 を評価するための視野スコア方法として有用と 考える。

\section{2. 質問票の構造について}

本質問票の構造を明らかにするために、視能 に関連する 31 項目の主成分分析を行った。その 結果、本質問票は第 1 主成分である段差の把握 成分、第 2 主成分である外側・順応成分、第 3 主成分である羞明成分とで構成されることがわ かった。

段差の把握成分は歩行の安全確保のためには 特に重要な評価項目であり、歩行の総合能力を 表すことが示唆された。これは階段昇降におい て、周辺視野残存者に比べて求心性視野障害者 で特に不自由に感じているという報告 ${ }^{18)}$ や、下 方の視野が制限されると床の高さの把握が不確 かになるという報告 ${ }^{19)}$ と一致した。

外側・順応成分のうち、外側成分については 左右にある障害物や物体に接触するというこ とを示し、周囲の歩行環境に関する視覚情報 の不足として歩行の安全性と能率性に影響す ると考える。Lovie-Kitchinら ${ }^{11}$ は、頭の高さ （140cm 以上）の水平で大きな障害物の回避が 最も困難であったと述べている。また、順応成 分は明順応と暗順応の遅延により、移動時に照 明状態の変化の対応に時間を要し、能率的な歩 行への支障をきたすと考える。照度の変化につ いてBlack $ら^{8)}$ は網膜色素変性患者が低照度下 で歩行パフォーマンスが低下したと報告した。 また、我々の調查は網膜色素変性患者の割合が 多く、自覚症状として暗順応の遅延があるた め、順応成分が自覚的歩行困難の評価に重要で あると考えられた。

第 3 主成分の羞明成分は、網膜色素変性患者 の自覚症状であることから抽出されたと考え た。Turano ${ }^{4)}$ の調査では、網膜色素変性患 者は高グレアの場所の歩行の困難性が強かった 
ことを報告している。羞明は減能グレアとして 物体の形状の把握や歩行環境が不明瞭になる等 の視覚情報の制限により歩行の安全性の低下に つながると考える。

視能障害者に対する歩行困難の質問票評価の 報告(多〈()-6)、18)、20)-22)、Bibby ら ${ }^{6)}$ (様々な原 因疾患の視能障害者を対象に、Turano ら $^{4), 5)}$ の質問票と視能の関係について検討した結果、 最も困難な歩行状況は高グレアの場所の歩行で あったと報告している。しかし、我々が作成し た質問票では段差の把握が歩行に最も必要な要 素であった。本質問票がTuranoらの質問票と 最も異なる点は、Turanoらの質問票が様々な 移動状況についての項目を含むことであり、そ れぞれの項目における視能の影響度が複雑で十 分明らかにできないと考えられた。本質問票の 各項目は視能との関連を意味づけて作成してい るため、視能評価との関連を説明しやすい利点 がある。視能の活用と視能以外の感覚や白杖な どの技術の活用を指導する歩行訓練において意 義があると考える。

\section{3. 視能スコア（FVS） と自覚的歩行困難との 関係について}

質問票のスコアに影響の強い視能変数は、 FFSに次いでFASであった。これは視能障害 による自覚的歩行困難への影響因子として、視 力よりも視野が重要であることを示している。 過去の報告においても視野が自覚的歩行困難を 評価するための主要な予測因子であることが示 されている7)-12)。しかし、視野測定の方法や測 定眼、測定範囲は様々であり、統一の必要があ ると考える。

今後は、黄斑疾患などによる中心視野障害の 患者に扔ける自覚的歩行困難の評価に応用する ための検討が必要であり、さらに網膜色素変性 と緑内障を含めた疾患別の自覚的歩行困難の特 性を明確にすることが必要と考える。

\section{参考文献}

1 ) 深井小久子: 視能矯正を考える. 日視会誌 33 : 21-29, 2004.

2 ) 深井小久子: 視能矯正の理念. 丸尾敏夫, 久保
田伸枝, 深井小久子(編): 視能学第2版. 193195, 文光堂, 東京, 2011.

3 ）厚生労働省 (internet)：https://www.mhlw. go.jp/houdou/2002/08/h0805-1. html(accessed 2018-12-30)

4 ) Turano KA, Geruschat DR, Stahl JW, Massof RW: Perceived visual ability for independent mobility in persons with retinitis pigmentosa. Invest Ophthalmol Vis Sci 40: 865-877, 1999.

5 ) Turano KA, Massof RW, Quigley HA: A self-assessment instrument designed for measuring independent mobility in RP patients: Generalizability to glaucoma patients. Invest Ophthalmol Vis Sci 43: 2874-2881, 2002.

6 ) Bibby SA, Maslin ER, McIlraith R, Soong GP: Vision and self-reported mobility performance in patients with low vision. Clin Exp Optom 90: 115-123, 2007.

7 ) Marron JA, Bailey IL: Visual factors and or orientation-mobility performance. Am J Optom Physiol Opt 59: 413-426, 1982.

8 ) Blak A, Lovie-Kitchin JE, Arnold N, Murrish $\mathrm{J}$ : Mobility performance with retinitis pigmentosa, Clin Exp Optom 80: 1-12, 1996.

9 ) Haymes S, Guest D, Heyes A, Johnston A: Mobility of people with retinitis pigmentosa as a function of vision and psychological variables. Optom Vis Sci 73: 621-637, 1996.

10) Geruschat DR, Turano KA, Stahl JW: Traditional measures of mobility performance and retinitis pigmentosa. Optom Vis Sci 75: 525-537, 1998.

11) Lovie-Kitchin JE, Mainstone JC, Robinson J, Brown B: What areas of the visual field are important for mobility in low vision patient. Clinical Vision Sciences 5: 249-263, 1990.

12) Black A, Wood JM, Lovie-Kitchin JE: Inferior field loss increases rate of falls in older adults with glaucoma. Optom Vis Sci 88: 1275-1282, 2011.

13) Colenbrander $\mathrm{A}$ : The functional vision score: 
A coordinated scoring system for visual impairments, disabilities, and handicaps. In: Kooiman AC, Looijestijn PL, et al (Ed): Low vision: Research and new developments in rehabilitation studieds in health technology and informatics. 552-561, IOS Press, Amsterdam, 1994.

14) Colenbrander A: Visual standards-aspects and ranges of vision loss (internet): https:// lists.w3.org/Archives/Public/public-lowvision-comments/2016AprJun/att0003/ Colenbrander_Visual_Standards_Aspects_ and_ranges_of_vision_loss_with_emp....pdf (accessed 2018-12-30)

15) American Medical Association: The visual system. In: Guindes to the evaluation of permanent impairment, 6th ed. American Medical Association, Chicago, 281-319, 2007.

16）田淵昭雄, 菊入 昭：ロービジョンの総合的 リハビリテーション:理論と実践. 54-67, 自由 企画, 東京, 2010.

17) Fuhr P, Holmes L, Fletcher D, Swanson M, Kuyk T: The AMA guides functional vision score is a better predictor of vision-targeted quality of life than traditional measures of visual acuity or visual field extent. Vis Impairment Res 5: 137-146, 2003.

18）井上賢治, 柏瀬光寿, 柳原崇男, 松田雄二, 原 利明, 間瀬樹省,他: ロービジョン者の都市・ 建築空間の移動における歩行パフォーマンス 調查. 日本ロービジョン学会誌 13: 73-76, 2013.

19) Timmis MA, Bennett SJ, Buckley JG: Visuomotor control of step descent: Evidence of specialised role of the lower visual field. Exp Brain Res 195: 219-227, 2009.

20）山縣祥隆, 寺田木綿子, 鈴木 温, 三村 治 : 視野障害患者の移動困難度評価における Esterman disability scoreの有用性に関する 臨床統計学的研究. 日眼会誌 114: 14-22, 2010.

21）田村美華, 小野峰子, 坂本保夫: 緑内障患者の 歩行パフォーマンス評価 歩行支援のための 課題の明確化. 東北文化学園大学医療福祉学 部リハビリテーション学科紀要 12: 13-21, 2016.

22）柳原崇男, 北川博巳, 齋藤圭亮, 三星昭宏 : ロービジョン者の視覚機能と外出時の歩行問 題の関係に関する研究. 土木計画学研究・論 文集２5: 525-533, 2008. 